\title{
Juvenil Dermatomiyozitte Farklı Klinik Fenotipler ve Prognoz: Referans Hastane Deneyimi
}

\author{
Different Clinical Phenotypes and Prognosis in Juvenile \\ Dermatomyositis: Reference Hospital Experience \\ Elif ÇELIKEL, Fatma AYDIN, Zahide EKICI TEKIN, Tuba KURT, Cüneyt KARAGÖL, Nilüfer TEKGÖZ, \\ Müge SEZER, M. Mehveş KAPLAN, Serkan COŞKUN, Banu ÇELIKEL ACAR
}

Sağlık Bilimleri Üniversitesi, Ankara Şehir Hastanesi, Çocuk Hastanesi, Romatoloji Kliniği, Ankara, Türkiye

\section{öz}

Amaç: Bu çalışmada, juvenil dermatomiyozit (JDM) tanısı ile takip edilen çocukların klinik özelliklerinin, laboratuvar bulgularının ve prognozunun değerlendirmesi amaçlanmıştır.

Gereç ve Yöntemler: Ocak 2005-Nisan 2021 tarihleri arasında merkezimiz Çocuk Romatoloji Kliniği'nde JDM tanıSı alan, en az 6 ay izlemine devam edilen, 17 çocuğun tıbbi kayıtları geriye dönük olarak değerlendirildi.

Bulgular: JDM tanılı 17 hastanın 10'u (\%59) kızdı. Hastaların ortanca yaşı 8 (1.5-14)'dü. Tanıdan önceki semptom süresi ortanca 2.5 (1-36) ay; ortalama takip süresi ortanca 24 (6-156) aydı. İlk başvuruda hastaların 15'inde (\%88.2) cilt bulgusu, 14'ünde (\%82.4) proksimal kas güçsüzlüğü tespit edildi. Başvuruda hastaların 8'inde (\%47) eritrosit sedimantasyon hızı ve C-reaktif proteinde yükseklik saptanırken 12'sinde (\%70.6) laktat dehidrogenaz, 12'sinde (\%70.6) aspartat aminotransferaz, 13'ünde (\%76.5) alanin aminotransferaz, 9'unda (\%53) kreatinin kinaz yüksekliği saptandı. Miyozit spesifik antikorlar; 5/17 hastada çalışıldı; 4 hastada pozitif bulundu. Kas biyopsisi 6 hastaya yapıldı ve inflamatuar miyozit ile uyumlu bulundu. On üç hastaya ekstremite manyetik rezonans görüntüleme yapıldı ve 10 hastada aktif miyozit gösterildi. Tüm hastalara başlangıç tedavisi olarak steroid ve eş zamanlı olarak metotreksat başlandı. Üç hastada metotreksat yan etkisi nedeni ile mikofenolat mofetil/ siklosporin A verildi. Iki hastada kalsinozis gelişti. Son takipte 13 hastanın steroid tedavisi kesilebildi. Bir hasta immünsüpresif ajan olmaksızın, 16 hasta immünsüpresif ajanlarla remisyondaydı. İki hasta 18 yaşın üzerinde olduğu için erişkin romatoloji kliniğine devredildi.

Sonuç: JDM çocukluk çağında nadir görülen bir hastalık olmasına rağmen kalsinozis ve vaskülopatiye ikincil ciddi komplikasyonlara neden olabilir. JDM'li tüm çocuklar yakından takip edilmelidir.

Anahtar Sözcükler: Çocukluk çağı, Jüvenil Dermatomiyozit, Prognoz

(1)

ÇELIKELE

AYDIN F

EKICI TEKIN Z

KURT T

KARAGÖL C

TEKGÖZ N

SEZER M

KAPLAN MM

COSKUNS

ÇELIKEL ACAR B
0000-0003-0129-4410 $0000-0003-0306-7473$ $0000-0002-5446-667 x$ 0000-0003-3711-8347 0000-0002-2987-1980 0000-0002-2235-4489 0000-0002-9254-9935 0000-0002-8012-2774 $0000-0003-2568-9329$ 0000-0002-1808-3655

\begin{abstract}
Çıkar Çatışması / Conflict of Interest: Tüm yazarlar adına, ilgili yazar çıkar çatışması olmadı̆̆ııı belirtir.
Etik Kurul Onayı / Ethics Committee Approval: Çalıșma için Ankara Şehir Hastanesi, 2 Nolu Klinik Araştırmalar Etik Kurul'undan E2-21-531 numaralı onay alınmışıı.

Yazarların katkısı / Contribution of the Authors: ÇELIKEL E: Araștırma ve/veya makalenin hipotezini veya fikrini olușturan, Sonuçlara ulașmak için planlama/metodoloji belirleme, Araștırma/çalıșmanın sorumluluğunu üstlenmek, ilerlemenin seyrini denetlemek, Hasta takibinde sorumluluk almak, ilgil biyolojik malzemelerin toplanması, veri yönetimi ve raporlama, deneylerin yürütülmesi, Sonuçların mantıksal olarak Yorumlanması ve sonuçlandırıması, Çalışma için gerekli literatür taramasında sorumluluk almak, Çalışmanın bütününün veya önemli bölümlerinin yazımında sorumluluk almak, Yazım ve dilbilgisi dışında bilimsel olarak gönderilmeden önce makaleyi gözden geçirme. AYDIN F: Araştırma ve/veya makalenin hipotezini veya fikrin oluşturan, Sonuçlara ulaşmak için planlama/metodoloji belirleme, Araştırma/çalışmanın sorumluluğunu üstlenmek, ilerlemenin seyrini denetlemek, Hasta takibinde sorumluluk almak, ilgili biyolojik malzemelerin toplanması, veri yönetimi ve raporlama, deneylerin yürütülmesi, Sonuçların mantıksal olarak Yorumlanması ve sonuçlandırılması, Çalıșma için gerekli literatür taramasında sorumluluk almak, Çalıșmanın bütününün veya önemli bölümlerinin yazımında sorumluluk almak, Yazım ve dilbilgisi dışında bilimsel olarak gönderilmeden önce makaleyi gözden geçirme. EKiCI TEKiN Z: Hasta takibinde sorumluluk almak, ilgili biyolojik malzemelerin toplanması, veri yönetimi ve raporlama, deneylerin yürütülmesi. KURT T: Hasta takibinde sorumluluk almak, ilgili biyolojik malzemelerin toplanması, veri yönetimi ve raporlama, deneylerin yürütülmesi. KARAGÖL C: Hasta takibinde sorumluluk almak, ilgili biyolojik malzemelerin toplanması, veri yönetimi ve raporlama, deneylerin yürütülmesi. TEKGÖZ N: Hasta takibinde sorumluluk almak, ilgili biyolojik malzemelerin toplanması, veri yönetimi ve raporlama, deneylerin yürütülmesi. SEZER M: Hasta takibinde sorumluluk almak, ilgili biyolojik malzemelerin toplanması, veri yönetimi ve raporlama, deneylerin yürütülmesi, Sonuçların mantıksal olarak Yorumlanması ve sonuçlandırıması. KAPLAN MM: Hasta takibinde sorumluluk almak, ilgili biyolojik malzemelerin toplanması, veri yönetimi ve raporlama, deneylerin yürütülmesi. COŞKUN S: Hasta takibinde sorumluluk almak, ilgili biyolojik malzemelerin toplanması, veri yönetimi ve raporlama, deneylerin yürütülmesi. CEELIKEL ACAR B: Araștırma ve/veya makalenin hipotezini veya fikrini olușturan, Sonuçlara ulașmak için planlama/metodoloji belirleme. Araștırma/çalıșmanın sorumluluğunu üstlenmek makalen hotezi yürütülmesi, Sonuçların mantıksal olarak Yorumlanması ve sonuçlandırılması, Çalıșma için gerekli literatür taramasında sorumluluk almak, Çalışmanın yürütülmesi, Sonuçların mantıksal olarak Yorumlanması ve sonuçlandırılması, Çalışma için gerekli literatür taramasında sorumluluk almak, Çalışmanın
bütününün veya önemli bölümlerinin yazımında sorumluluk almak, Yazım ve dilbilgisi dişında bilimsel olarak gönderilmeden önce makaleyi gözden bütününün
geçirme.

Atıf yazım șekli / How to cite : Çelikel E, Aydın F, Ekici Tekin Z, Kurt T, Karagöl C, Tekgöz N, ve ark. Juvenil Dermatomiyozitte Farklı Klinik Fenotipler ve Prognoz: Referans Hastane Deneyimi. Türkiye Çocuk Hast Derg 2021;15: 331-336.
\end{abstract}

Yazışma Adresi / Correspondence Address: Elif ÇELIKEL

Sağlık Bilimleri Üniversitesi, Ankara Șehir Hastanesi,

Pediatrik Romatoloji Bölümü, Ankara, Türkiye

E-posta: elifcelikel06@gmail.com
Geliş tarihi/ Received : 07.05.2021 Kabul tarihi / Accepted : 11.06.2021 Elektronik yayın tarihi : : 15.06.2021 Online published

DOI: 10.12956/tchd.934302 


\section{ABSTRACT}

Objective: The aim of this study is to evaluate the clinical features, laboratory findings and prognosis of children followed up with a diagnosis of juvenile dermatomyositis (JDM).

Material and Methods: The medical records of 17 children who were diagnosed with JDM in the Pediatric Rheumatology Clinic of our center between January 2005 and April 2021 and were followed up for at least 6 months were evaluated retrospectively.

Results: Ten of the 17 patients (59\%) with a diagnosis of JDM were girls. Median age was 8 (1.5-14). Median duration of symptoms before diagnosis was 2.5 (1-36) months; the median follow-up time was 24 (6-156) months. Skin findings were detected in 15 (88.2\%) patients and proximal muscle weakness in 14 (82.4\%) patients at the first admission. Erythrocyte sedimentation rate and C-reactive protein elevation were detected in 8 (47\%) patients at admission, while 12 (70.6\%) had lactate dehydrogenase, 12 (70.6\%) aspartate aminotransferase, and 13 (76.5\%), alanine aminotransferase and 9 (53\%) increased creatine kinase. Myositis-specific antibodies; assessed in 5/17 patients; found positive in 4 patients. Muscle biopsy was performed on 6 patients and was found to be compatible with inflammatory myositis. Magnetic resonance imaging of the limbs was performed in 13 patients and active myositis was demonstrated in 10 patients. Steroid and simultaneous methotrexate were started as initial therapy in all patients. Mycophenolate mofetil/cyclosporine A was given to three patients because of the side effect of methotrexate. Calcinosis developed in two patients. Steroid therapy could be discontinued in 13 patients at the last follow-up. One patient was in remission without an immunosuppressive agent, and 16 patients were in remission with immunosuppressive agents. Two patients were transferred to the adult rheumatology clinic because they were over 18 years old.

Conclusion: Although JDM is a rare disease in childhood, it can cause serious complications secondary to calcinosis and vasculopathy. All children with JDM should be closely monitored.

Key Words: Childhood, Juvenile dermatomyositis, Prognosis

\section{GiRiş}

Juvenil dermatomiyozit (JDM) çocukluk çağında en sık görülen idiopatik inflamatuar miyopati grubudur $(1,2)$. Klasik olarak proksimal kas güçsüzlüğü ve heliotrop döküntü, Gottron papülleri gibi cilt bulguları görülürken bağırsak, akciğer ve kalp gibi diğer organ tutulumları da tabloya eşlik edebilir (1-3). Oldukça nadir görülen bu çocukluk çağı romatizmal hastalığının sıklğı coğrafi bölgelere göre değişmekle beraber 2-4/1.000.000'dur $(4,5)$. Hastaliğın etiyolojisi tam olarak bilinmemekle birlikte otoimmünite, genetik yatkınlık, çevresel faktörler ve enfeksiyöz ajanlar gibi birçok neden suçlanmaktadır. Genetik olarak duyarlı bireylerde, çevresel risk faktörlerinin eklenmesiyle, edinsel ve kazanılmış immün sistemin aktivasyonu ve kronik inflamasyon zemininde oluşan bir otoimmün anjiyopati gelişimi olmaktadır (3).

Inflamasyon etkin tedaviyle kontrol altına alınamazsa kalsinozis, vaskülopatiye ikincil organ hasarı gibi morbiditeyi arttıran komplikasyonlar gelişebilir. Juvenil dermatomiyozitin erken teşhisi ve uygun tedavisi, remisyon ve ciddi komplikasyonların önlenmesini sağlayabilir (6-8).

Bu çalışmada merkezimizde son 15 yıldır takip edilen JDM tanılı çocukların klinik, laboratuvar ve patolojik özellikleri değerlendirilmiştir.

\section{GEREÇ ve YÖNTEMLER}

Ocak 2005-Nisan 2021 tarihleri arasında merkezimiz Çocuk Romatoloji Kliniğii'nde 18 yaşından önce JDM tanısı alan, en az 6 ay izlemine devam edilen, 17 çocuğun tıbbi kayıtları geriye dönük olarak değerlendirildi. JDM tanısı Bohan ve Peter'in kriterlerine dayanılarak konuldu (9). Bu kriterlere göre kesin JDM tanısı için karakteristik cilt tutulumuna(heliotrop döküntü, Gottron papülleri) ek olarak üç kriterin (simetrik proksimal kas güçsüzlüğü, iskelet kas enzimlerinde yükselme, elektromiyografide (EMG) miyopati ile uyumlu değişiklikler ve kas biyopsisi histopatolojisi), olası JDM tanısı için klasik cilt döküntüsüne ek olarak iki kriterin olması yeterlidir. JDM tanısı ile izlenen ancak tıbbi kayıtları eksik olan ya da takip süresi 6 aydan kısa olan hastalar çalışma dışı bırakıldı. Hastaların cinsiyet, yaş, başlangıç semptomları ve klinik özellikleri, semptomların başlangııı ile tanı arasında geçen süre, tanı anındaki laboratuvar değerleri, EMG, kas biyopsisi ve magnetik rezonans görüntüleme (MRG) sonuçları, takip süresi, uygulanan tedavi ve sonuçları ile komplikasyonları kaydedildi. Laboratuvar parametreleri arasında eritrosit sedimentasyon hIzI (ESH), C-reaktif protein (CRP), laktat dehidrojenaz (LDH), aspartat aminotransferaz (AST), alanin aminotransferaz (ALT), kreatinin kinaz (CK), antinükleer antikor (ANA) vardı. Miyozit spesifik antikor (MSA) değerlendirilen hastaların sonuçları kaydedildi. Çalışma için Ankara Şehir Hastanesi, 2 Nolu Klinik Araştırmalar Etik Kurul'undan E2-21-531 numaralı onay alınmıştır.

\section{İstatistik Analiz}

Veriler SPSS programı (SPSS version 20.0; SPSS Inc., Chicago, IL, USA) kullanılarak değerlendirildi. Sonuçlar, ortalama \pm standart sapma veya median (minimum-maksimum) olarak verildi. Kategorik değişkenler n (\%) olarak özetlendi.

\section{BULGULAR}

Çalışmaya dahil edilen 17 JDM tanıı hastanın \%59 kızdı. Hastaların ortanca yaşı 8 (1.5-14)'dü. Tanıdan önceki semptom süresi ortanca 2.5 (1-36) aydl. Ortalama takip süresi ortanca 24 (6-156) aydı. Başvuru sırasında en sık olan şikâyetler; cilt 
Tablo I: Juvenil dermatomiyozit hastalarının tanı anında demografik, klinik ve laboratuvar özellikleri.

\begin{tabular}{|c|c|}
\hline & Bulgular $(n=17)$ \\
\hline Cinsiyet; kız, n (\%) & $10(59)$ \\
\hline $\begin{array}{l}\text { Şikayetlerin başladığı yaş; ortanca (min- } \\
\text { max) }\end{array}$ & $7.2(1.5-13)$ \\
\hline Tanı yaşı; ortanca (min-max) & $8(1.5-14)$ \\
\hline Takip süresi; ortanca (min-max)(ay) & $24(6-156)$ \\
\hline $\begin{array}{l}\text { Klinik bulgular } \\
\text { Cilt değişiklikleri, }{ }^{*} \\
\text { Heliotrop döküntü, * } \\
\text { Gottron's papülleri, }{ }^{*} \\
\text { Malar döküntü, }{ }^{*} \\
\text { Ödem, }{ }^{*} \\
\text { Telenjektazi, }{ }^{*} \\
\text { Artrit/artralji, } \\
\text { Miyalji,, } \\
\text { Kas güçsüzlüğü, }{ }^{*} \\
\text { Halsizlik, }{ }^{*} \\
\text { Ateş, }{ }^{*}\end{array}$ & $\begin{array}{r}15(88,2) \\
8(47.1) \\
13(76.5) \\
12(70.6) \\
3(17.6) \\
4(23.5) \\
7(41.2) \\
13(76.5) \\
14(82.4) \\
14(82.4) \\
2(11.8)\end{array}$ \\
\hline $\begin{array}{l}\text { Laboratuvar bulguları } \\
\text { ESH (mm/saat) ortanca (min-max) (0-20) } \\
\text { CRP (mg/dL ortanca (min-max) (0-0.8) } \\
\text { LDH (0-298 U/L) } \\
\text { AST (40 U/L) } \\
\text { ALT (40 UI/L) } \\
\text { CK (32-294 U/L) } \\
\text { ANA pozitifliği n }(\%)\end{array}$ & $\begin{array}{c}24.7(5-81) \\
0.8(0.01-5.4) \\
766(213-1983) \\
218(17-907) \\
143(15-776) \\
3714(45- \\
26179) \\
5(29.4)\end{array}$ \\
\hline
\end{tabular}

ESH: Eritrosit sedimentasyon hizı, CRP: C-reaktif protein, LDH: Laktat dehidrogenaz, AST: Aspartat aminotransferaz, ALT: Alani aminotransferaz, CK: Kraetinin kinaz, ANA: Anti-nükleer antikor, *: n(\%)

döküntüleri, güçsüzlük, halsizlik ve eklem ağrısıydı. Hastaların 15 'inde (\%88.2) cilt bulgusu, 14'ünde (\%82.4) proksimal kas güçsüzlüğü tespit edildi. Başvuru anında sadece 8 (\% 47) hastada ESH ve CRP'de yükseklik saptanırken 12 hastada (\%70.6) LDH, 12 hastada (\%70.6) AST, 13 hastada (\%76.5) ALT, 9 hastada (\%53) CK referans aralığın üzerinde saptandı. Antinükleer antikorlar, 17 hastanın 5 'inde pozitif saptandı. MSA; 5/17 hastada çalışıldı ve 4 hastada pozitif bulundu. Hastaların tanı anındaki demografik verileri ve detaylı klinik ve laboratuvar özellikleri Tablo l'de özetlenmiştir.

Onyedi hastanın 14'üne EMG yapıldı. İki hastaya yaşlarının küçük olması ve bir hastanın da yaygın ödeminin olması nedeni ile EMG yapılamadı. Kas biyopsisi 6 hastaya yapıldı ve inflamatuar miyozit ile uyumlu bulundu. On üç hastaya proksimal kas gruplarını değerlendirmek amacıyla ekstremite MRG yapıldı ve 10 hastada MRG ile aktif miyozit gösterildi. Hastaların EMG, MRG ve kas biyopsi sonuçları Tablo Il'de verilmiştir. Tüm hastalara başlangıç tedavisi olarak steroid verildi. Yedi hastaya yaygın kas tutulumu, yutma güçlüğü, disfoni, yaygın ödem gibi nedenlerle intravenöz (IV) bolus metilprednizolon ile tedaviye başlandı (Hasta 1, 3, 7, 10, 12, 16, 17). Geriye kalan 10 (\%58.8) hastaya oral 2 mg/ $\mathrm{kg} /$ gün olarak steroid tedavisi ve tüm hastalara eș zamanlı olarak metotreksat başlandı. Hastalardan 3'ünde (Hasta 2, 3,
16) metotreksat yan etkisi nedeni ile mikofenolat mofetil veya siklosporin A verildi. Hastalara uygulanan tedaviler Tablo I'de verilmiştir. Tedaviye ortalama yanıt süresi ortanca 3 (1-6) aydı. İki hastada kalsinozis gelişti. Hasta 2'ye yaygın kalsinozis nedeni ile pamidronat tedavisi başlandı. Pamidronat tedavisinin üçüncü ayından sonra kalsinoziste gerileme olduğu görüldü. Son takipte 13 hastanın steroid tedavisi kesilebildi. Bir hasta immünsüpresif ajan olmaksızın remisyonda, 16 hasta immünsüpresif ajanlarla remisyondaydı. Metotreksat tedavisi altında remisyonda olan 2 hasta 18 yaşın üzerinde olduğu için erişkin romatoloji kliniğine devredildi.

\section{TARTIŞMA}

Juvenil dermatomiyozit, çocukluk çağındaki düşük insidansına rağmen çocukluk çağının en sık görülen idiyopatik inflamatuar miyopatisidir ve tipik deri döküntüleri ve kas güçsüzlüğü ana bulgularıdır (1,2). 1975 ylında Bohan ve Peter tarafindan önerilen tanı kriterleri hala hastalı̆ıın tanısının konulmasında altın standart olmaya devam etse de, yaygın olarak yeni kullanılmaya başlanan kapilleroskopi ve otoantikorlar, görüntüleme yöntemleri tanı koymaya yardımcı olmaktadır.

Çocukluk çağının en yaygın görülen inflamatuar miyoziti olan JDM grubunda tipik cilt bulguları bu çalşmada bulunduğu gibi sık görülmektedir (\%88.2). Tipik cilt bulguları ile artmış CK, LDH, AST ve ALT gibi kas enzim düzeylerinin birlikteliği tanı için yol gösterici olmaktadır.

Hastalığın başlangıcı genellikle 5-14 yaşları arasındadır (1-3). Ortalama yaş Campanilho-Marques ve ark. (10) çalışmasında 5.2 yll (3.3-9.7), Barut ve ark. (11) çalışmasında $6.6 \pm 4.1$ yıl (216) olarak bulunmuştur. JDM halsizlik, kolay yorulma ve bazen çocuklarda değerlendirilmesi kolay olmayan kas güçsüzlüğü gibi bulgularla kendini gösterdiği için tanı alması zaman alabilir. Tipik cilt bulguları geliştiğinde daha hızlı tanı konur. Sun ve ark. yirmi yıllık deneyimlerini yansıtan 39 JDM hastasını kapsayan çalışmasında en sık görülen başvuru bulgularının Gottron papülü (\%82.1) ve kas güçsüzlüğü (\%82.1) olduğunu bildirdi (12). Çalışmamızdaki hastalarda da en sık saptanan başlangıç bulguları benzer bulundu. Tipik JDM bulguları ile hastalığın klinisyenin aklına gelmesi mümkün olsa da Peter ve Bohran'ın tanı kriterleri ile kesin ya da olası JDM tanısı kesinleștirilmektedir. Günümüzde hastalarda saptanan JDM'ye özel kapilleroskopi bulguları, MRG ile gösterilen akut miyozit ve MSA'ların varlığı daha noninvaziv ve kolay şekilde konulabilmesini sağlamaktadır.

Magnetik rezonanas görüntüleme, kaslardaki inflamasyonun değerlendirilmesi ve kas biyopsi alanlarının tespiti için yararıdır. Kasın inflamasyonunu yansıtan kas ödemi, T2 ağırlıkl/yağ basklı ya da STIR sekansları ile gösterilebilir. Kronik hastalık seyrinden kaynaklanan yağ infiltrasyonu da tanıya yardımcı olmaktadır (13). Son yıllarda merkezimizde tipik klinik bulguları olan hastalarda MSA tespiti ile beraber kullanılan MRG'nin 
Tablo II: Hastaların klinik Özellikleri ve takip sonuçları.

\begin{tabular}{|c|c|c|c|c|c|c|c|c|c|c|}
\hline Hasta & $\begin{array}{l}\text { Şikayet } \\
\text { başlama } \\
\text { yaşı (yıl) }\end{array}$ & Cinsiyet & $\begin{array}{l}\text { Başvuru } \\
\text { şikayeti }\end{array}$ & $\begin{array}{l}\text { Kas } \\
\text { MRG }\end{array}$ & Kas biyopsisi & EMG & $\begin{array}{l}\text { Otoantikor } \\
\text { (MSA) }\end{array}$ & $\begin{array}{l}\text { Takip } \\
\text { süresi } \\
\text { (yıl) }\end{array}$ & Tedavi & Komplikasyon \\
\hline 1 & 11 & K & $\begin{array}{l}\text { Yüzünde } \\
\text { kızarıklık, } \\
\text { güçsüzlük }\end{array}$ & Miyozit & - & Normal & - & 3.5 & $\begin{array}{l}\text { Bolus } \\
\text { prednizolon, } \\
\text { Oral prednizolon, } \\
\text { Metotreksat, } \\
\text { Hidroksiklorokin }\end{array}$ & Yok \\
\hline 2 & 8 & K & $\begin{array}{l}\text { Güçsüzlük, } \\
\text { halsizlik }\end{array}$ & - & Miyozit & Miyopati & - & 7.5 & $\begin{array}{l}\text { Oral prednizolon, } \\
\text { Metotreksat, } \\
\text { Siklosporin, } \\
\text { IVIG, } \\
\text { MMF, } \\
\text { Pamidronat }\end{array}$ & Kalsinozis \\
\hline 3 & 4.5 & $E$ & $\begin{array}{l}\text { Döküntü, } \\
\text { halsizlik, } \\
\text { çabuk yorulma }\end{array}$ & Miyozit & - & Miyopati & MDA5 & 2 & $\begin{array}{l}\text { Prednizolon, } \\
\text { Metotreksat, } \\
\text { MMF }\end{array}$ & Yok \\
\hline 4 & 6 & K & $\begin{array}{l}\text { Döküntü, } \\
\text { halsizlik }\end{array}$ & - & Miyozit & Miyopati & - & 2 & $\begin{array}{l}\text { Prednizolon, } \\
\text { Metotreksat }\end{array}$ & Yok \\
\hline 5 & 3 & K & $\begin{array}{l}\text { Döküntü, } \\
\text { eklem ağrısı }\end{array}$ & Normal & - & Normal & - & 6 & $\begin{array}{l}\text { Prednizolon, } \\
\text { Metotreksat }\end{array}$ & Yok \\
\hline 6 & 1,5 & K & $\begin{array}{l}\text { Halsizlik, } \\
\text { ateş, } \\
\text { karın ağrısı, } \\
\text { döküntü }\end{array}$ & Miyozit & - & Miyopati & - & 13 & $\begin{array}{l}\text { Prednizolon, } \\
\text { Metotreksat }\end{array}$ & Yok \\
\hline 7 & 11 & K & $\begin{array}{l}\text { Döküntü, } \\
\text { kas ağrısı }\end{array}$ & Miyozit & - & Miyopati & - & 3 & $\begin{array}{l}\text { Prednizolon, } \\
\text { Metotreksat }\end{array}$ & Yok \\
\hline 8 & 8.5 & $\mathrm{~K}$ & $\begin{array}{l}\text { Döküntü, } \\
\text { kas ağrısı }\end{array}$ & Miyozit & - & Miyopati & - & 1.5 & $\begin{array}{l}\text { Prednizolon, } \\
\text { Metotreksat }\end{array}$ & Yok \\
\hline 9 & 6.5 & K & $\begin{array}{l}\text { Güçsüzlük, } \\
\text { yürüme zorluğu }\end{array}$ & Miyozit & $\begin{array}{l}\text { İnflamatuar } \\
\text { miyozit }\end{array}$ & Miyopati & - & 1 & $\begin{array}{l}\text { Prednizolon, } \\
\text { Metotreksat }\end{array}$ & Yok \\
\hline 10 & 9.5 & $E$ & $\begin{array}{l}\text { Kas ağrısı, } \\
\text { halsizlik, } \\
\text { döküntü }\end{array}$ & Miyozit & $\begin{array}{l}\text { İnflamatuar } \\
\text { miyozit }\end{array}$ & Miyopati & Anti Mi2 & 1.5 & $\begin{array}{l}\text { Prednizolon, } \\
\text { Metotreksat, } \\
\text { MMF }\end{array}$ & Yok \\
\hline 11 & 9 & $E$ & $\begin{array}{l}\text { Güçsüzlük, } \\
\text { döküntü, } \\
\text { eklem şişliği }\end{array}$ & - & $\begin{array}{l}\text { İnflamatuar } \\
\text { miyozit }\end{array}$ & Miyopati & Negatif & 2 & $\begin{array}{l}\text { Prednizolon, } \\
\text { Metotreksat }\end{array}$ & Yok \\
\hline 12 & 1.5 & K & $\begin{array}{l}\text { Ateş, halsizlik, } \\
\text { döküntü }\end{array}$ & Normal & - & - & - & 12 & $\begin{array}{l}\text { Prednizolon, } \\
\text { Metotreksat }\end{array}$ & Yok \\
\hline 13 & 7 & $E$ & $\begin{array}{l}\text { Döküntü, } \\
\text { halsizlik }\end{array}$ & Miyozit & - & Miyopati & - & 4 & $\begin{array}{l}\text { Prednizolon, } \\
\text { Metotreksat }\end{array}$ & Yok \\
\hline 14 & 4 & $E$ & $\begin{array}{l}\text { Yürümede } \\
\text { bozulma, } \\
\text { döküntü }\end{array}$ & - & $\begin{array}{l}\text { İnflamatuar } \\
\text { miyozit }\end{array}$ & - & - & 1 & $\begin{array}{l}\text { Prednizolon, } \\
\text { Metotreksat }\end{array}$ & Yok \\
\hline 15 & 13 & $\mathrm{~K}$ & $\begin{array}{l}\text { Eklem şişliği, } \\
\text { döküntü }\end{array}$ & Normal & - & Normal & Anti-TIF1y & 1 & $\begin{array}{l}\text { Prednizolon, } \\
\text { Metotreksat, } \\
\text { Hıdroksiklorokin }\end{array}$ & Yok \\
\hline 16 & 10.5 & $E$ & $\begin{array}{l}\text { Vücutta şişlik, } \\
\text { halsizlik }\end{array}$ & Miyozit & - & - & NXP2 & 6 ay & $\begin{array}{l}\text { IVIG, } \\
\text { Prednizolon, } \\
\text { Metotreksat, } \\
\text { MMF }\end{array}$ & Kalsinozis \\
\hline 17 & 7.5 & $E$ & $\begin{array}{l}\text { Kollarda ve } \\
\text { bacaklarda } \\
\text { şişlik, } \\
\text { halsizlik, } \\
\text { ateş, } \\
\text { yürüyememe }\end{array}$ & Miyozit & - & Miyopati & - & $2 \mathrm{yll}$ & $\begin{array}{l}\text { Prednizolon, } \\
\text { Metotreksat, } \\
\text { IVIG }\end{array}$ & Yok \\
\hline
\end{tabular}

MSA: Miyozit spesifik antikor, MMF: Mikofenolat mofetil, IVIG: Intravenöz immünglobulin 
kullanılması kas biyopsisi gibi invaziv işlemlerin yapıma oranını azaltmıştır. Sınıflandırma kriterlerinin gelecekteki revizyonunun, tanının doğrulanması için MRG bulgularını içermesi uygun olacaktır.

Juvenil miyoziti olan hastaların \%60-70'inde MSA veya miyozit ilişkili antikorlar (MAS) olarak sınıflandırılan otoantikorlar bulunmaktadır (14). MSA'ların genelde JDM'nin de içinde yer aldığı idiopatik inflamatuar miyopatilerle, MAS'ların ise diğer bağ dokusu hastalıkları ya da overlap sendromlarla ilişkili olduğu gösterilmiştir. Anti-Mi2 bilinen en klasik JDM otoantikoru olarak kabul edilse de hastaların sadece \%4-10'unda bulunmaktadır. $\mathrm{Bu}$ antikor olan hastaların tipik olarak cilt ve kas tutulumu vardır. Illginç bir șekilde, anti-Mi2 ile ilişkili JDM hastalarında başvuru sırasında bulgular șiddetli iken, bu hastalar tipik olarak geleneksel tedaviye iyi yanıt verir ve iyi prognoza sahiptir. Çalışmamızda hasta 10'da anti-Mi2 antikoru saptanmıştı. Bu hastamızın başlangıçta kas bulguları ağır olmasına rağmen steroid tedavisine iyi yanıt vermişti, fakat izleminde metotreksat intoleransı gelişmesi nedeni ile tam yanıt süresi 3 aya kadar uzamıştı. Öte yandan, anti-NXP2 (\%15-23) ve anti-TIFY (\%18-32) olan hastaların geleneksel tedavilere dirençli olma olasılığı daha yüksektir (14). Anti-NXP2'li hastalarda, artmış gastrointestinal kanama, ülser ve disfaji riskine ek olarak daha şiddetli kas hastalığı ile ilişkili bulunmuştur (15). JDM'nin klinikopatolojik alt gruplarını araştıran bir çalışmada, anti-NXP2'nin kas biyopsisinde şiddetli kas güçsüzlüğü, gastrointestinal tutulumu ve belirgin şiddetli iskemik özellikleri olan bir hasta alt grubunda daha sık ortaya çıktı̆ı̆ın saptamıştır. Üstelik anti-NXP2'li hastalar daha agresif ve takip süresi boyunca daha düşük remisyon oranı ile beraber daha agresif tedaviye intiyaç duymaktadır $(14,15)$. Çalışmamızda yer alan hasta 16'da anti-NXP2 saptanmıştır. Bu hasta kas gücü ve fonksiyonlarının birlikte değerlendirildiği "CMAS" hastallk skoruyla kas gücünün sıfır olduğu gösterilen, yaygın anazarka tarzı ödemi olan, bir erkek hastaydl. Pulse metilprednisolon, intravenöz immünglobulin (IVIG) ve metotreksat tedavisine rağmen tedavinin 4. haftasında yatağa bağımlı̆̆ı tam düzelmemişti. Ayrıca yoğun immünsüpresif tedaviye rağmen tedavinin üçüncü ayında sağ uyluğunda kalsinozis gelişimi meydana geldi. Kalsinozis, juvenil başlangıçlı hastalıkta daha sık görülen, dermatomiyozitin bilinen bir komplikasyonudur. Anti-NXP2 otoantikorları İngiltere'deki hastalarda kalsinozis gelişimi ile ilişkilendirilmiştir, ancak daha büyük bir hasta grubu analiz edildiğinde bu ilişki Gunawardena ve ark. tarafından gösterilememiştir (14-18).

Anti-NXP2 ile ilişkili kötü prognozun aksine, anti-TIF1y olan hastalarda daha hafif kas tutulumu olabilir (14-17). Anti-TIF1y olan alt grup, ülserasyon gibi daha şiddetli cilt hastalığı ile; Amerika Birleşik Devletleri'nden bir çalışmada ise JDM'nin geç komplikasyonu olan lipodistrofi ile ilişkilendirilmiştir (19). Anti-TIF1y olan yetișkin miyozit hastalarının tanıdan sonraki üç yll içinde artmış malignite riski olduğu gösterilmiştir, ancak bu ilişki JDM'de gösterilememiştir (20). Çalışmamızda hasta 15'de anti-TIF1y antikoru saptanmıştı. Bu hastamızın kas bulguları belirgin değildi ve EMG, kas MRG normal bulunmuştu, ancak JDM için tipik cilt bulguları ile beraber MSA pozitifliğinin olması ile tanı konulabilmişti. Çalışma grubumuzdaki hasta 3'de ise Anti-MDA5 otoantikoru olduğu gösterildi. Bu antikor tanımlanan hastaların hem klinik hem de histolojik olarak daha hafif kas hastalığı olduğu ancak interstisyel akciğer hastalığı geliştirme olasılığının arttığı saptanmıştır $(21,22)$. Anti-MDA5 ile genç Doğu Asya kohortlarında hızlı ilerleyen interstisyel akciğer hastalığı ve bununla yüksek ilişkili mortalite bildirilmiştir (22). Tipik cilt bulguları ve kas güçsüzlüğü ile prezente olan ve takibinin üçüncü yllına ulaşan hastamızda steroid, mikofenolat mofetil tedavisi ile remisyon sağlanmıştır ve akciğer tutulumu henüz bulunmamaktadır.

Juvenil dermatomiyozitte inflamasyonun hızlı ve etkin tedaviyle kontrol altına alınması kalsinozis gibi komplikasyonları azaltır. Tedavi disfaji, dispne, cilt ülseri, yaygın ödem veya gastrointestinal kanama gibi șiddetli hastalıkla ilişkili bulgulara ve hayati organ tutulumuna göre düzenlenmelidir. JDM tedavisinde öncelikle kortikosteroid ve metotreksatın birlikte kullanıması önerilmektedir. Yeni tanı konulmuş şiddetli hastalı̆ı̆ olan veya dirençli hastalarda siklofosfamidin tedavi planında yer aldığı daha yoğun tedavi uygulanmalıdır. Tüm bu tedavilere rağmen iyileşme görülmediğinde siklosporin, IVIG, rituksimab veya infliksimab önerilmektedir (23). Çalışmamızda ki tüm hastalara başlangıç tedavisi olarak steroid ve metotreksat bașlasak da 3 hastamızda metotreksat intoleransı veya yan etkisi geliştiği için tedavinin steroid ve mikofenolat mofetil/siklosporin olarak düzenlenmesi gerekti. Yine hasta 2, 7, 16, 17 dirençli ve șiddetli hasta olarak değerlendirilerek IVIG ile tedavi edildi. Hastalarımızın hepsinde tedavi ile remisyon sağlandı ve ancak hasta 2'de yaygın kalsinozis gelişti ve tedaviye bifosfonat eklendi. Tedavinin 6. ayında kalsinoziste azalma sağlanabilmişti. Traineau ve ark 1980'den beri yayınlanmış olan sistemik skleroz ve JDM'deki kalsinozis kutis tedavisi ile ilgili toplamda 30 çalıșmayı (288 hasta) incelemiştir. Çeşitli çalışmaların sonuçlarına göre diltiazem ve bifosfonatların yararlı tedavi seçenekleri olabileceği düşünülmüştür. Biyolojik tedaviler göz önüne alındığında ise inflamasyonun iyi kontrolünü sağlayan rituksimabın hem JDM hem de sistemik skleroz tedavisinde umut verici sonuçlar ortaya koyduğunu, ayrıca tümör nekroz faktör inhibitörlerinin JDM'nin tedavisinde faydalı olabileceğini vurgulamışlardır (24).

Çalışmamızın kısıtlıı̆̆ı, tek merkezde yapılmış olması ve retrospektif olarak verilerin değerlendirilmesidir. Ayrıca çalışmamız son 15 yıllık verileri yansıtmaktadır ve çalışmanın başlangıç döneminde takip edilen hastaların hepsine kas MRG yapılamamış ve MSA çalışılamamıştır. Ancak çocukluk çağının oldukça nadir görülen bu romatolojik hastalı̆ı̆ ile ilgili ülkemize ait verilerin sunulması önem tașımaktadır.

Sonuç olarak, JDM çocukluk çağında nadir görülen bir hastalık olmasına rağmen kalsinozis ve vaskülopatiye ikincil ciddi komplikasyonlara neden olabilir. JDM'li tüm çocuklar hem hastalığa ait hem de immunsupresif ilaçlara bağı olarak gelişebilecek komplikasyonlar ve hastalığın prognozu açısından 
yakından takip edilmelidir. Ülkemizdeki JDM tanısı konulmuş çocukların klinik spektrumunu yansıtmak ve prognozlarını değerlendirmek için çok merkezli çalışmalara intiyaç vardır.

\section{KAYNAKLAR}

1. Woo P, Laxer RM, Sherry DD. Juvenile dermatomyositis. In: Woo $\mathrm{P}$, Laxer RM, Sherry DD, editors. Pediatric Rheumatology in clinical practice. 1st ed. London: Springer 2007:66-76.

2. Compeyrot-Lacassagne S, Feldman BM. Inflammatory myopathies in children. Pediatr Clin North Am 2005;52:493-520.

3. Feldman BM, Rider LG, Reed AM, Pachman LM. Juvenile dermatomyositis and other idiopathic inflammatory myopathies of childhood. Lancet 2008;371:2201-12.

4. Symmons DP, Sills JA, Davis SM. The incidence of juvenile dermatomyositis: results from a nation-wide study. $\mathrm{Br} J$ Rheumatol 1995;34:732-6.

5. Mendez EP, Lipton R, Ramsey-Goldman R, Roettcher P, Bowyer S, Dyer A, et al. NIAMS Juvenile DM Registry Physician Referral Group US incidence of juvenile dermatomyositis, 1995-1998: results from the National Institute of Arthritis and Musculoskeletal and Skin Diseases Registry. Arthritis Rheum 2003;49:300-5.

6. Fisler RE, Liang MG, Fuhlbrigge RC, Yalcindag A, Sundel RP. Aggressive management of juvenile dermatomyositis results in improved outcome and decreased incidence of calcinosis. J Am Acad Dermatol 2002;47:505-11.

7. Kim S, El-Hallak M, Dedeoglu F, Zurakowski D, Fuhlbrigge $\mathrm{RC}$, Sundel RP. Complete and sustained remission of juvenile dermatomyositis resulting from aggressive treatment. Arthritis Rheum 2009;60:1825-30.

8. Traineau H, Aggarwal R, Monfort JB, Senet P, Oddis CV, Chizzolini $\mathrm{C}$, et al. Treatment of calcinosis cutis in systemic sclerosis and dermatomyositis: A review of the literature. J Am Acad Dermatol 2020;82:317-25.

9. Bohan A, Peter JB. Polymyositis and dermatomyositis (first of two parts). N Engl J Med 1975;292:344-7.

10. Campanilho-Marques R, Deakin CT, Simou S, Papadopoulou C, Wedderburn LR, Pilkington CA; Juvenile Dermatomyositis Research Group (JDRG). Retrospective analysis of infliximab and adalimumab treatment in a large cohort of juvenile dermatomyositis patients. Arthritis Res Ther 2020 15;22:79.

11. Barut K, Aydin PO, Adrovic A, Sahin S, Kasapcopur O. Juvenile dermatomyositis: a tertiary center experience. Clin Rheumatol 2017;36:361-6.
12. Sun $\mathrm{C}$, Lee $\mathrm{JH}$, Yang $\mathrm{YH}$, Yu HH, Wang LC, Lin YT, Chiang BL. Juvenile dermatomyositis: a 20-year retrospective analysis of treatment and clinical outcomes. Pediatr Neonatol 2015;56:31-9.

13. Sasaki H, Kohsaka H. Current diagnosis and treatment of polymyositis and dermatomyositis. Mod Rheumatol 2018;28:91321.

14. Tansley Sarah L, Simou Stefania, Shaddick Gavin, Betteridge Zoe E, Almeida Beverley, Gunawardena Harsha. Autoantibodies in juvenile-onset myositis: Their diagnostic value and associated clinical phenotype in a large UK cohort. Journal of Autoimmunity 2017;84:55-64.

15. Aouizerate J, De Antonio M, Bader-Meunier B, Barnerias C, Bodemer $C$, Isapof $A$, et al. Muscle ischaemia associated with NXP2 autoantibodies: a severe subtype of juvenile dermatomyositis. Rheumatology 2018;57:873-9.

16. Rider LG, Shah M, Mamyrova G, Huber AM, Rice MM, Targoff IN, Miller FW, et al. The myositis autoantibody phenotypes of the juvenile idiopathic inflammatory myopathies. Medicine 2013;92:223-43.

17. Tansley SL, Betteridge ZE, Shaddick G, Gunawardena H, Arnold $\mathrm{K}$, Wedderburn LR, et al. Calcinosis in juvenile dermatomyositis is influenced by both anti-NXP2 autoantibody status and age at disease onset. Multicenter Study Rheumatology 2014;53:220408.

18. Gunawardena H, Wedderburn LR, Chinoy H, Betteridge ZE, North J, Ollier WE, et al. Autoantibodies to a 140-kd protein in juvenile dermatomyositis are associated with calcinosis. Arthritis Rheum 2009;60:1807-14.

19. Gunawardena H, Wedderburn LR, North J, Betteridge Z, Dunphy $\mathrm{J}$, Chinoy $\mathrm{H}$, et al. Juvenile Dermatomyositis Research Group UK Clinical associations of autoantibodies to a p155/140 kDa doublet protein in juvenile dermatomyositis. Rheumatology 2008;47:324-8.

20. Almeida B, Tansley S, Simou S, Gunawardena H, McHugh N, Wedderburn L. Anti-synthetase autoantibody is seen in patients with overlap myositis in the UK cohort of patients with Jveunile Dermatomyositis. Rheumatology 2017;84:55-64.

21. Kobayashi N, Takezaki S, Kobayashi I, Iwata N, Mori M, Nagai K, et al. Clinical and laboratory features of fatal rapidly progressive interstitial lung disease associated with juvenile dermatomyositis. Rheumatology 2015;54:784-91.

22. Tansley SL, Betteridge ZE, Gunawardena H, Jacques TS, Owens $\mathrm{CM}$, Pilkington $\mathrm{C}$, et al. Anti-MDA5 autoantibodies in juvenile dermatomyositis identify a distinct clinical phenotype: a prospective cohort study. Arthritis Res Ther 2014;16:R138.

23. Enders FB, Bader-Meunier B, Baildam E, Constantin T, Dolezalova $\mathrm{P}$, Feldman BM, et al. Consensus-based recommendations for the management of juvenile dermatomyositis. Ann Rheum Dis 2017;76:329-40.

24. Traineau H, Aggarwal R, Monfort JB, Senet P, Oddis CV, Chizzolini C, et al. Treatment of calcinosis cutis in systemic sclerosis and dermatomyositis: A review of the literature. J Am Acad Dermatol 2020;82:317-25. 